\title{
Tail docking in horses: a review of the issues
}

\author{
D. Lefebvre ${ }^{1 \dagger}$, D. Lips ${ }^{2}$, F. O. Ödberg ${ }^{4}$ and J. M. Giffroy ${ }^{3}$
}

${ }^{1}$ Animal Welfare Counci-Ministry of Social Affair, Food Chain Security and Environment-DG4 (CITES and Animal Welfare), 40 Place Victor Horta, 1060 Bruxelles, Belgium; ${ }^{2}$ Centre for Science, Technology and Ethics-Kasteelpark Arenberg 30, 3001 Leuven, Belgium; ${ }^{3}$ Department of Anatomy and Ethology of Domestic Animals, Faculties of Namur, 6 rue Muzet, 5000 Namur, Belgium; ${ }^{4}$ Department of Animal Nutrition, Genetics and Ethology, Ghent University, Heidestraat 19, 9820 Merelbeke, Belgium

(Received 30 November 2006; Accepted 24 May 2007)

Routinely performed painful procedures are of increasing interest and, in 2001 (Royal Order, May 17), Belgium prohibited docking in several vertebrates including horses. In 2004, opponents to this decision submitted a Bill (Doc51 0969/001) to Parliament, intending to obtain derogation for Belgian draught horses, which were traditionally docked. The Animal Welfare Council of Belgium, an official body advising the Minister of Public Health, was asked to evaluate this complex question, including biological, ethical and socio-economic aspects, on the basis of the available peer-reviewed studies. In this context, this study reviews legal aspects (overview of the European legislation), zootechnic aspects (uses of the Belgian draught horse) and biological aspects (pain potentially related to docking; horses' welfare linked to insect harassment and hygiene, communication and reproduction) of tail docking in draught horses. We conclude that (1) there is no benefit for horses in tail docking, including Belgian draught horses, (2) potential advantages of docking are essentially in favour of humans and these advantages could be scrupulously re-evaluated, taking into account practices of other countries. Therefore, there is no need to dock any horse other than for veterinary reasons.

Keywords: animal pain, animal welfare, horses, legislation, tail docking

\section{Introduction}

Routinely performed painful procedures, one question of importance in the field of farm animal welfare, are of increasing interest (Bonney, 2006; Weary et al., 2006) and Belgium prohibited tail docking in some vertebrates, including horses, in 2001 (Royal Order, May 17; Law 1986).

Opponents to this decision submitted a Bill (Doc51 0969/ 001) to Parliament in March 2004, intending to obtain derogation for Belgian draught horses on behalf of 'the existence of a long tradition in this respect' (indeed, most draught horses were traditionally docked, especially Belgian draught horses as Trait Ardennais or Trait du Nord) and improvement by tail docking of handler security, breeding, hygiene and horses' welfare.

The Council of Animal Welfare of Belgium was then asked to evaluate these arguments on the basis of the available peer-reviewed studies. This work reviews the main arguments concerning tail docking of horses, in order to facilitate a more informed debate, using the proposed Bill as a basis of discussion due to its official and exhaustive

\footnotetext{
† Present address: INRA DISI-IST, RD 10, F-78026 Versailles, France. E-mail: lefebvre.diane@laposte.net
}

characters. First, the practical aspects of tail docking will be considered, i.e. the human point of view, such as handler security in the context of load pulling, mating aspects and some other uses of draught horses. Second, the possible implications of tail docking for horses will be evaluated, i.e. from the horse's point of view, such as health and welfare problems related to the amputation procedure, insect harassment and hygiene, and communication. These aspects are preceded by an overview of the European legislation.

\section{Overview of the European legislation}

European Convention for the Protection of Animals kept for Farming Purposes (European Council, Strasbourg, 10.III.1976) and the Protocol of Amendment to this Convention (European Council, Strasbourg, 6.Il.1992) concern 'any animal (including fish, reptiles or amphibians) bred or kept for the production of food, wool, skin or fur or for other farming purposes'. In these documents, no reference is made to docking. Only Article 2 of the Protocol of Amendment might be considered to refer to this problem: 'breeding procedures which cause or are likely to cause suffering or injury to any of the animals involved shall not be practised'. 
Particular conditions were established for pigs and poultry. Concerning pigs, Directives 91/630/EEC (Council of the European Union) and 2001/93/EC (Commission) lay down minimum standards. They state 'tail docking [...] must not be carried out routinely but only where there is evidence that injuries to [...] pigs' [...] tails have occurred. Before carrying out these procedures, other measures shall be taken to prevent tail biting and other vices taking into account environment and stocking densities. For this reason, inadequate environmental conditions or management systems must be changed. Any of the procedures described above shall only be carried out by a veterinarian or a person trained [... and] experienced in performing the applied techniques [...]. If castration or docking of tails is practised after the 7th day of life, it shall only be performed under anaesthetic and additional prolonged analgesia by a veterinarian.'

Note that tail docking of horses is banned in several European countries, either specifically or as an 'aesthetic operation'. This is the case, for instance, in Austria (Law on Animal Protection, no. 118/2004), Denmark (Danish Act on the Protection of Animals, 1991), Finland (Animal Welfare Act, 1 January 1996), Germany (Law on Animal Protection, 1933; Lizet, 1999), Ireland (Protection of Animals Act, 1965), Portugal (Decreto-Lei no. 276/2001), Norway (The Welfare of Animal Act, 20 December 1974, no. 73 and 16 June 1995), Sweden (The Animal Welfare Act, 19 February 1998) or the United Kingdom (Nicking of Horses Act, 1949). In other European countries, tail docking in horses is authorised. This is the case of Luxembourg (Règlement, 31 July 1987) and Spain, except for Cataluñia (Ley 22/2003 de Protección de los Animales) and Andalucía (Ley 11/2003 de Protección de los Animales).

Some particular cases may also be cited. In France and Italy, tail docking in horses is not banned but docked horses are either excluded from official manifestations (France: Arrêté Ministériel, 19 January 1996) or disapproved by the official draught horse association (Italy: Associazione Nazionale Allevatori des Cavallo Agricolo Italiano da Tiro Pesante Rapido), leading to an abandonment of this practice. On the contrary, in the Netherlands, the operation is banned but horses docked in countries where it is authorised are accepted in official manifestations (decision from the 'Nederlands College van Beroep voor Bedrijfsleven').

It would be useful to precise the legislative status of Belgian draught horses. Indeed, although they are generally used for farm purposes (agricultural or forestry work, meat production), some have no specific farm function. The question is thus about the category of these horses, given that the Directive 98/58/CE of the Council of the EU (20 July 1998), concerning Protection of Animals kept for Farming Purposes, specifies that 'this Directive lays down minimum standards for the protection of animals bred or kept for farming purposes. It shall not apply to animals intended for use in competitions, shows, cultural or sporting events or activities'. Are these horses some sort of 'pet animals', i.e. 'animals kept or intended to be kept by man [...] for private enjoyment and companionship', as they are in UK? If so, it should be noted that the European Convention for the Protection of Pet Animals affirms that 'Surgical operations for the purpose of modifying the appearance of a pet animal or for other non-curative purposes shall be prohibited and, in particular: the docking of tails.'

\section{Arguments for tail docking}

According to the Private Bill's authors, long tails represent a 'mortal danger' to handlers. Indeed, 'when beating their tail, horses may pass it above the rein used to guide them, making guiding them further impossible with an increased risk of bolting'. Based on this, 'traditional forest teamsters [would] refuse to work with intact draught horses'. 'Bandaging or braiding the tail [would] increase the risk of the tail passing over the cord. In addition, this procedure [(bandaging and braiding) would be a] torture when used on horses working over the whole day'.

The Private Bill's authors also put forward the 'survival of the Belgian draught horse' and, in this sense, 'an insufficient number of births', 'serious lesions of the sex of the stallion caused by the long tail of the mares', or 'greatly complicated' gynaecological examinations of mares with '[the impossibility] to carry out such examinations under hygienic and sterile conditions'.

\section{Handlers' security and load pulling}

A clear documentation precisely detailing the reasons for docking is very difficult to find. In general, in the literature devoted to Belgian draught horses, it is largely accepted that tail docking stems from problems linked to guiding horse teams for agricultural or forestry work. Schematically, a working horse team may be guided with a single rein ('cordeau' in French), two reins, or more, the choice of technique depending on the work to be done. In Belgium, a single rein is predominantly used. The main advantage of this technique is to allow the horse(s) to be guided with one hand, leaving the other free for other work (BrasseBrossard, 1988). Problems could rise from the tail, which may pass over the rein, impairing the control of the horse(s). However, this should not occur. Moreover, draught horses that are not under the control of the rein may still be under their teamster's voice control. In addition, draught horses are not known to bolt easily. On the contrary, they are known for their gentleness and their docility (see e.g. the 'National Stud farms' descriptions for Belgium, ${ }^{1}$ for France, ${ }^{2}$ or Sambraus (1994) for Germany).

Another problem related to the presence of the tail is the risk of snarling between the tail and the swing bar or the leader that may be whipped.

In Belgium, as in France, docking was the traditionally chosen solution. Braiding, shaving or bandaging could,

\footnotetext{
${ }^{1}$ http://www.kmbt-srctb.be/fr

${ }^{2}$ http://www.haras-nationaux.fr/portail/index.php?id $=3643 \& M P=2766-2640$
} 
however, also have been chosen. Concerning this last technique, even if traumas have been reported due to prolonged bandaging (Professor Frank Gasthuys, personal communication), it is questionable to qualify this practice as a 'torture instrument' in the absence of studies evaluating the epidemiology of such lesions and pain associated with bandaging.

Despite the problems outlined above, foresters working with long-tail horses may be seen in Belgium, Italy, France or Sweden (photos and interviews in Lefebvre (2006), see also the e-site of the FECTU ${ }^{3}$ ). In particular, Belgian forest teamsters generally accept the tail docking prohibition at the moment. On the other hand, in countries where horses are managed with guides (more than a single rein), tails are generally not managed, except by some hair shortening. Leaders still have a free hand, because they learn how to use their reins with one or two hands. Instances may be found in Sweden (Sidbäck, 1993) or in Germany, the homeland of Benno von Achenbach, founder of the Achenbach guide technique. For agricultural and forest work, these guides or reins may be joined in a similar way to that of 'cordeau'. In his work devoted to this last technique, Pape (1980) makes no mention either to the preparation of the horses' tail by braiding, binding or docking or to a potential risk stemming from a free tail. He, however, gives precise instructions for grooming the tail, according to its length (docked or not).

\section{Mating aspects}

In most horse breeds, the mare's tail should be bandaged prior to mating (Taylor, 1998). This seems particularly necessary for Belgian draught horses due to risk of lesions to the penis of the stallion. In addition, males exhibit little enthusiasm about mating, all the more after having being injured. The authors found, however, no scientific work concluding to 'serious lesions of the stallion penis caused by the long tail of mares', as specified in the proposed Bill, or considering that as a major mating problem, in any horse breed. No work was found on the enthusiasm of draught male horses to mate.

In addition, some breeders refute these arguments (Lefebvre, 2006) and the following arguments may additionally be considered. From an evolutionary point of view, if the mare's tail could actually induce severe lesions, (1) horses, or at least mares, would be at present naturally docked or 'shaved', owing to the fact that males would have avoided copulating with females having a long tail or tails with other 'dangerous' characters or (2) males would have developed a 'defensive strategy' consisting of a better protection of their penis against wounds potentially caused by the female tails. It is, however, possible that selection carried out by humans on Belgian draught horses led to a (i) 'dangerous' mare tail or to a (ii) particularly fragile male

\footnotetext{
3 Fédération Européenne du Cheval de Trait pour la promotion de son Utilisation (European Draught Horse Federation ): http://www.fectu.org/index.htm
}

penis but these points are not mentioned in the scientific literature. In addition, if a mare's tail, even bandaged, could cause 'serious lesions to the stallion penis', all mares would also be docked but they are not. In particular, other breeds of draught horses, as the French Percheron draught horse or the Britannic Shires, are not traditionally docked. In the same way, only half of the draught horses are docked in Canada, whatever the sex (Christie et al., 2004).

From this, mares' tails are unlikely to cause severe mating problems.

Concerning the major complications of gynaecological examinations of the mare given the '[impossibility] to carrying out such examinations under hygienic and sterile conditions', the same arguments exposed for mating as stated above may be considered. In particular, such a problem is not reported for other similar draught horse breeds, such as the Percheron, Shires, Clydesdales or Suffolk Punches.

\section{Other uses of the draught horses and renewal of the population}

The size of the population of draught horses is a direct consequence of their use by humans. Due to the development of increasingly powerful and/or improved machines, the population of draught horses is currently reduced in Belgium: from about 250000 in 1939 to about 6000 today. Even though it persists, the use of draught horses in forestry is currently questioned due to difficulties related to profitability (Thiry, 1994; Heidemann, 2002). Load-pulling uses related to leisure have recently been developed (tourism, sport, cultural manifestations).

Because of a reduced use of traction power added to a good meat yield, draught horses are currently destined to butchery. Horses bred in this context are docked in order to emphasise the 'meat quantity' available in their hindquarters. This use is, however, insufficient to maintain population size, and other uses, such as landscape maintenance by grazing horses, tend to be developed (Mercat, 1993; Bouillot, 2002). There is no evidence to suggest that these current uses require tail docking or that docking the tail in this context would increase the population of Belgian draught horses.

\section{Cosmetic aspects}

Although mainly practical reasons seem to have induced the tail docking practice in old times, aesthetic reasons cannot be dismissed (Dent, 1983; Cregier, 1990). Indeed, the horses' appearance is very important for stockbreeders. An example of horse presentation is given by BrasseBrossard in 1945 (1988): 'when possible, the horse should be led by a small man skilled with horses who will if the occasion arises make the horse look larger. The tail must be rolled up to make a rounded croup for all to see.' The same author specifies that 'one often shorten the hair of the tail of the foal, in order to more elegantly roll up the tail during work but one should not shorten as much as the Belgians 
who exaggerate to give the illusion of a beautiful croup.' This last comment underlines the cultural aspect of the perception of the horses' tail length (see also Dent, 1983; Cregier, 1990; Nebergall, 1999).

In this regard, according to Lizet (1991), tail docking in horses began in Great Britain in the 17th century, intended to distinguish English horses from French ones and to make a distinction between these schools. Initially associated with nicking (cutting some tail's muscles to make it stand up), it was strictly reserved for nobility. After the practise was questioned, it disappeared from Great Britain but spread in Western Europe for draught horses. Nicking, reflecting a similar aesthetic and cultural interest for horses' tail position, led to diverse practices of artificial tail elevation, such as the use of alcohol or ginger. These practices are also currently under discussion (Colter and Luttgen, 1994a and 1994b; Tozzini, 2003).

In conclusion, this short overview concerning uses of draught horses and cosmetic aspects illustrates the complexity of the question of the draught horse and its close link with the economic development of rural and forest areas (see also Lizet, 1999). In such a broad context, there is no evidence to suggest that the law on docking horses' tails should be revoked.

\section{Health and welfare problems related to the amputation procedure}

Authors of the Private Bill affirm that 'when done according to standards of good veterinary practice, docking is not incompatible with animal welfare'. In particular, 'when this intervention is well carried out, pain [would be] minimal and risks of complication very small'. Moreover, 'the operation can be totally painless when carried out with light sedation and an epidural anaesthesia'. From this, we present here a review on pain associated with the procedure, in particular in foals, the available ways of pain management and possible post-operative complications.

\section{Amputation procedures}

For a long time, docking was carried out using tongs or sorts of guillotines and finalised by a red iron cauterisation. Currently, the operation may be carried out either surgically or by ligature. Surgical docking requires an incision of the tail's skin and of the subjacent tissues (muscles, nerves, blood vessels and intervertebral discs). The incision is then sutured (Nebergall, 1999). Ligature may use rubber rings or other binding methods. Ligature induces necrosis of the distal part of the tail. Studies comparing epidemiology of these methods and their respective pain aspects and induced complications could be useful. Comparisons of different methods of docking have been extensively studied primarily in lambs (e.g. Lester et al., 1991; Graham et al., 1997), leading to some classifications of these procedures based on acute distress responses to these procedures
(Mellor and Stafford, 2000; see, however, Dinnis et al., 1999 for limitations of such classifications).

\section{Acute pain at the time of the amputation}

Pain perception relies on complex anatomical structures and physiological mechanisms (review in Loeser and Melzack, 1999; Le Bars and Willer, 2004; see also http://www.vet. ed.ac.uk/animalpain/). Pain intensity experienced by other individuals, and a fortiori by individuals of other species, may be evaluated by anatomical analogies and by physiological and behavioural criteria (Bateson, 1991; Molony and Kent, 1997; Weary et al., 2006). These criteria also help to evaluate animal welfare, a wide-ranging term including pain assessment (general aspects: review in Duncan, 2005; physiology: review in Axelrod and Reisine, 1984; Lightman et al., 2002; behaviour: review in Dawkins, 1990 and 2004; vocalisations: review in Manteuffel et al., 2004; stereotypies: review in Mason and Latham, 2004).

It should be noted that the measurement and perception of pain felt by animals is often subjective (Hawkins, 2003) and relies on psychological factors (Bennet and Perini, 2003b; Heleski et al., 2004) and philosophical prerequisites (Rollin, 1985; Preece and Fraser, 2000; Broom, 2006; see also open peer commentaries in Dawkins, 1990). The different pain scores attributed to different species (e.g. sheep and cattle) for a same operation (e.g. castration) illustrate this subjective aspect of the perception of pain felt by animals (Scott et al., 2003; Heleski et al., 2004). In these studies, scores also relied on several characteristics of the persons who attributed pain scores. As a consequence, the feeling of pain in animals is not systematically taken into account (Morton and Griffiths, 1985; Rollin, 1985; Noonan et al., 1996a) or not taught (McGlone and Hicks, 1993) and methods relieving it are insufficiently used (various species: Heleski et al., 2004; horse: Price et al., 2002; dog: Noonan et al., 1996a; cattle: Whay and Huxley, 2005).

Pain in horses at the time of the tail amputation (performed with or without anaesthesia) has not been measured. However, studies focussing on other mammals showed the painful character of amputations performed without anaesthesia. For instance, docking has been shown to be painful in dogs (review in Bennett and Perini (2003); http://www.defra.gov.uk/animalh/welfare/domestic/awbill consulttaildocking.pdf), sheep (Molony et al., 1993; Graham et al., 1997; Kent et al., 1998) and cattle (review in Stull et al., 2002; Aubry, 2005). Both castration and docking of piglets have also been shown to induce specific behavioural changes, such as vocalisations (Noonan et al., 1994; Weary et al., 1998; Marx et al., 2003; Puppe et al., 2005), activity disturbances and abnormal movements of the mutilated areas (McGlone et al., 1993; Hay et al., 2003).

The specific case of pain in foals and newborn mammals According to the Private Bill's authors, pain in docked horses would be minimised by the fact that the intervention is carried out on very young foals (between 2 weeks and 
3 months). That supposes that the operation is potentially painful but that very young individuals perceive the pain less than older ones. This idea of limited perceived pain in very young individuals relies on the persistent current assumption that immature nervous systems lead to weaker pain. This idea is translated into laws. For instance, the European Directive 2001/93/CE, concerning the protection of pigs, states that 'if castration or docking of tails is practised after 7th day of life, it shall only be performed under anaesthetic and additional prolonged analgesia by a veterinarian.' In other words, anaesthesia is not required for amputations on piglets under 7 days of life.

However, farm animals appear to be able to suffer soon after birth, when breathing oxygenates the newborn sufficiently to remove the inhibition of pain functions of the brain (Mellor and Diesch, 2006). In this sense, foals of between 1 week and 6 months perceive and respond to both superficial and deep cutaneous painful stimulation, suggesting the necessity to anaesthetise them at the time of an operation (Dunlop, 1994). In another study, Noonan et al. (1996b) showed that every pup vocalised intensely when docked. The period of most strident vocalisation corresponded to the actual moments of tail amputation, of piercing the skin for suture placement and of pressure on the suture material as the knot was tied. No more shrieks were recorded during the recovery period and puppies expressed a significant reduction of whimpers in the seconds following the operation.

Pain in foals is a subject in current development, as most pain measurements have been carried out on adults, using behavioural (Price et al., 2003) and physiological parameters (Hamra et al., 1993; McCarthy et al., 1993); the same for stress measurements (McGreevy and Nicol, 1998). In a similar way, pain in human newborns was ignored for a long time. Their capacity to feel pain and, more generally, to undergo a stress when submitted to surgical operations or diverse manipulations has been studied only relatively recently (see, for instance, Anand, 1990; Gunnar et al., 1988 and 1992; Anand et al., 2006).

\section{Post-operative pain and chronic health problems}

Pain associated with amputation and other surgical interventions is not limited to the time of the operation. For instance, horses exhibit physiological and behavioural signs of post-operative pain during the 48-h period following an operation (exploratory celiotomy: Pritchett et al., 2003; arthroscopic surgery: Price et al., 2003). Similar results in other species showed that pain related to an operation may continue from several hours (celiotomy in rat: Roughan and Flecknell, 2003) to several days (tail docking in pigs: Hay et al., 2003; in lambs: Rhodes et al., 1994) after the operation. Except for the Rhodes et al. study, these results on pain duration were limited by the duration of observation, suggesting longer pain duration.

Amputations may also lead to neurological problems (Mathews and Osterholm, 1972). In this way, an increased prevalence of neuroma is observed several months after docking (lamb: French and Morgan, 1992; dog: Gross and Carr, 1990; pig: Simonsen et al., 1991); neurectomy (horse: Said and Khami, 1984; rat: Fischer et al., 1983); or beak trimming in poultry (Breward and Gentle, 1985; Gentle, 1986). Neuroma is not systematically associated with acute or chronic pain. Pain, caused by abnormal spontaneous neuroma's activity or to increased sensibility of it (Swanson, 1961; Scadding, 1981; Blumberg and Jänig, 1984), is influenced by the healing process quality, itself relying on the type of operation, the age and the quantity of tissue removed (horse: Said and Khami, 1984; poultry: Gentle et al., 1995; Lunam et al., 1996). Skin adhesion subsequent to tail docking has also been observed in docked dogs (Carr, 1979). An epidemiological study would complete these results in foals, where docking is still practised. Finally, infectious complications have been observed that are likely to induce paralysis in horses (Professor Frank Gasthuys; personal communication).

\section{Pain management}

In agreement with these results concerning pain stemming from amputation, authors of the proposed Bill affirm that docking may be 'totally painless, when undergone with light sedation and epidural anaesthesia'. It should, however, be noted that inadequate depth or inappropriate use of anaesthetics and/or analgesics may lead to an insufficiently pain-free state, even if the animal is not moving during the operation (Short, 1998). Such a problem should, however, not outweigh the anatomical and physiological particularities of foals that make foals more sensitive to anaesthetics than older individuals (Dunlop, 1994; Foursin, 1995; see also Anand, 1990).

In addition, general anaesthesia is not risk-free. Mortality rate for horses that have undergone surgery with general anaesthesia varies from $0.68 \%$ to $8 \%$ (Lievens, 2001; Proudman et al., 2006). Various factors related to the operation, like the treated disease, the type of operation, the choice of anaesthetic agents and the intervention/ anaesthesia duration, influence the mortality rate (Johnston et al., 2004; Proudman et al., 2006). Health status, age and breed (in relation with the horses' size) of the anaesthetised animal also influence the mortality rate (Proudman et al., 2006). In addition to increased mortality risks, general anaesthesia may also produce post-operative complications, rating between $6 \%$ and 15\% (Lievens, 2001; Mason et al., 2005), as for instance neuropathies, myopathy, temporary blindness or post-anaesthetic colic (Lievens, 2001; Joubert et al., 2005).

Furthermore, even if associated with lower mortality and morbidity rates (for contradictory results, see Mason et al., 2005), complementary studies could be useful concerning pain relief efficiency of epidural analgesia under clinical conditions even if efficient products are still available (Olbrich and Mosing, 2003). Additional knowledge is also needed concerning the evaluation of pain (Holm et al., 
Lefebvre, Lips, Ödberg and Giffroy

2006) and stress related to chirurgical operations and concerning evaluation and management of the postoperative pain (short review of analgesia in horses in Taylor, 2003).

\section{Consequences of tail docking for horses}

According to the Private Bill's authors, 'there [is] no scientific reason to prohibit docking'. On the contrary, 'from a welfare point of view, there [are] more reasons to dock than not to. [Indeed, it would be] erroneous to believe that the Belgian draught horse loses, as a consequence of docking, its best weapon against insect attacks.' Moreover, keeping 'the tail of the draught horse [would] increase hygiene problems [because] it increases the dirtying of the tail's internal face by the manure and so [would be] the ideal place for parasite attacks (Acarus spp., in particular)'.

From these arguments developed in the proposed Bill, we review here the impact of the tail on insect chasing and hygiene, its role in horses' communication and possible influences on social behaviour.

\section{Insect harassment}

Many insects may bother horses, including Hymenoptera, such as bees, wasps, hornets or bumblebees. Some Arthropods are also parasites, such as various mites (Class: Arachnid; Order: Acari), including harvest ticks (Family: Trombididae), scab mites and itch mites (resp. Families: Psoroptidae and Sarcoptidae), and numerous flies (Class: Insects; Order: Diptera), including horseflies (Family: Tabanidae and some Rhagionidae) and mosquitoes (Families: Simuliidae, Ceratopogonidae and Culicidae) (Soulsby, 1982; Heath, 1994).

In addition to their parasitic aspect, inducing blood losses and potentially painful wounds when tissues are bitten or perforated, insect attacks may impair horse health, through disease transmission or allergy induction. For instance, some mosquitoes are vectors of the Orbivirus, responsible for the equine plague, and of nematodes, responsible for onchocercose, ulcers may stem from botflies attacks (Cogley and Cogley, 1999) and Culicoides, in particular Culicoides obsoletus, are causal agents of a summertime skin hypersentivity usually occurring in pastured horses or in horses that are in open or poorly screened stables (Anderson et al., 1991). Finally, severe insect attacks may also be detrimental to the reproductive success of horses, given that constantly harassed individuals may occasionally fail to maintain proximity or nurse their young or cease foraging (in Keiper and Berger, 1982; see also Byford et al., 1992 for effects of ectoparasites on cattle production).

It should be noted that numerous factors could influence insect attacks, as shown in sheep, where myiasis prevalence and attack level include various factors such as insect biology, including ecological factors (e.g. regional distribution of blowfly strike in French et al., 1992), sheep management (e.g. French et al., 1994b) or pharmacokinetic of pharmaceutical treatments (Hall and Wall, 1995; Fenton et al., 1998a and 1998b). If demonstrated, the tail docking effect is then only one of these numerous factors, whose importance $v$. other factors need furthermore to be quantified.

Prevention of insect attacks: behaviour of intact horses Horses have natural weapons against insect attacks (review in McDonnell, 2003): movements of hair (mane and tail), head and neck, shivering, stamping and location shifts or refuge seeking. Defensive behaviours may be carried out alone or with conspecifics. Indeed, when in a group, two or more horses may stand beside one another, usually headto-shoulder or head-to-tail, swishing their tails, removing insects from the head and hindquarters of the participants. Moreover, it should be noted that, even when alone, horses might protect broader areas with their tail than simply their hindquarter, notably due to their neck mobility. Lastly, like other mammalian hosts, horses might answer insect attacks by modifying the social structure (distance between individuals or group size), long-distance movements and habitat shifts (Duncan and Cowtan, 1980; Keiper and Berger, 1982; Rutberg, 1987).

Due to differences in their biology and ecology, bothering insects exhibit various preferred zones of attack, leading horses to react differently according to the type of harassing insect. E.g. horses react to botfly attacks by moving but only those horses that take off in a gallop leave ovipositing flies behind. However, the flies are able to catch up with the horse after it comes to a stop, and this within a few seconds (Cope and Catts, 1991; Cogley and Cogley, 2000).

Prevention of insect attacks: behaviour of docked horses The authors found no mention (1) of docking preventing (or curing) infections or insect attacks in horses or (2) of work evaluating the impact of docking on the intensity of insect attacks in horses. On the contrary, due to the positive relation between insect densities and tail swishing (Duncan and Cowtan, 1980), the frequency of tail swishing per minute was used as an indirect measure of pest harassment (Keiper and Berger, 1982). It has also been observed that docked individuals may walk a good deal in order to avoid bothering insects. This behaviour results in unnecessary horse fatigue, associated with unnecessary energy consumption and pasture damaging (Mr Cottrant, French Representative for Draught Horses; personal communication). In such cases, it can reasonably be concluded that the absence of a tail actually reduces welfare of pastured horses. Such a position was officially adopted in fact by the 'Associazione Nazionale Allevatori des Cavallo Agricolo Italiano da Tiro Pesante Rapido', the National Association for the Italian Draught Horses (Dr Pigozzi, Director of the ANACAITPR; personal communication). Finally, it should be noted that tail docking is not proposed as a preventive treatment against insect harassment in non-draught horses. 
Results obtained on cattle agree with these elements (Stull et al., 2002). Cattle and horses share behaviours of insect avoidance. In particular, they use their tail in a similar way (Kiley-Worthington, 1976; Ralley et al., 1993). Tail docking in dairy cattle may have originated for two reasons: to control disease transmission and to improve milker comfort. Tails may be contaminated with dung when cows defecate, lie down or are manipulated by handlers. Tail movements can then splatter faeces and other material onto the cow or her herdmates, contaminating udders and increasing the risks of mastitis or other udder infections. However, the effect of docking is not clearly demonstrated. Depending on studied indices, either no difference was found between docked and undocked dairy cows in udder cleanliness or health (Tucker et al., 2001) or docked cows were found to be cleaner than undocked ones (Eicher et al., 2001). On the other hand, docked cows have more flies due to a significant increase in fly numbers on the rear legs. They also exhibited significantly more fly-avoidance behaviours than cows with intact tails, and these behaviours were essentially directed towards the rear. Tail swings were the most frequent fly-avoidance behaviour recorded in intact cows. Finally, docked cows stood more and exhibited increased general restlessness than intact cows when the fly numbers increased, indicating that they were uncomfortable (Eicher et al., 2001; Eicher and Dailey, 2002).

Tail docking is also performed in sheep. However, the context is quite different: principal insect attacks concern the Calliphoridae and Sarcophagidae (Dipterous inducing myiasis) that are particularly dangerous because larvae grow in sheep tissues, digging in. Attacks, mainly observed in the area around the tail, seem linked to dung spread by the tail (Snoep et al., 2002). In such a context, docking is widely considered to prevent faecal soiling and fly strike. However, scientific studies are not unanimous: whereas French et al. (1994a) showed that intact lambs underwent more fly attacks than docked lambs, in relation with improved rear cleanliness, two other studies (French et al., 1994b; Snoep et al., 2002) showed that docking was associated neither to a lower myiasis prevalence nor to less insect attacks. In addition, docking lambs too short can increase the incidence of fly strike (Watts and Marchant, 1977; Watts and Luff, 1978; see also Watts and Perry, 1975; Watts et al., 1978). Furthermore, in spite of their results, French et al. (1994a) concluded that more adequate control of diarrhoea and development of reliable alternative methods of blowfly strike management should be considered, because of the dichotomy between the proportion of docked lambs (about 100\%) and the relatively low proportion of lambs likely to be struck (125 attacks for 3172 studied lambs).

Prevention of insect attacks: management of horses Most effective solutions against insect attacks and parasitic infections appear to be preventive measures (Medica et al., 1996; Taylor, 1998), such as clean feeding and watering facilities and clean and fresh shelters, possibly treated with insecticides. Environmental treatment (cleared pastures, drained ponds) and pasture maintenance (regular removal of manure, periodic fallow for pastures, avoiding overcrowding of horses, avoiding the spreading of fresh manure on pastures) also limit insect attacks. Faecal sites need special attention because they enhance some insect development. In particular, they could be used as mating sites for Gastrophilus intestinalis (Cogley and Cogley, 2000). Lastly, sheltering horses during the hottest hours of summer or providing them with mosquito nets or bonnets protecting eyes (the simplest being a bonnet with fringes) mechanically protect them from some attacks (Soulsby, 1982). Concerning insecticides, their effective duration may be reduced by horse sudation. In addition, chemical treatments must be carefully managed in order to limit risks of insect resistance developing, as shown in sheep (Leathwick et al., 1995).

Another important practice is regular close inspection (or even brushing) of horses. Although simple, but expensive in time, such a practice offers many advantages. On the one hand, it enhances prevention of many diseases related to hygiene and allows a veterinary monitoring permitting detection of any hair or skin anomaly. For instance, of the three principal mites attacking horses, Psoroptes is of particular interest in the docking question, principally attacking horses' hair. Its prevention is clearly enhanced by regular control of skin condition (Professor Michel Ectors, vicePresident of the Belgian Horse Confederation; personal communication). On the other hand, it may enhance horse welfare, likely stimulating skin functions, enhancing superficial circulation and relieving tiredness (Brasse-Brossard, 1988; Heidemann, 2002). Moreover, grooming enhances man-horse contacts, which is likely to improve this relation and thus the horse's effectiveness at work (Brasse-Brossard, 1988; Sidbäck, 1993).

\section{Tail and communication}

This aspect is not treated in the proposed Bill. The tail is, however, an important element of communication between horses. Tail movements can be classified into dorso-ventral movements (i.e. up and down), which are closely associated with changes in postural tonus, and lateral tail movements (tail wagging: Kiley-Worthington, 1976 and 1997). Tail elevation is generally associated with head and neck elevation with head and ears oriented towards the subject of interest to the animal. This elevated posture, rather than being related to a particular situation, indicates an overall vigilant state in relation to a general state of excitation, such as sexual arousal, aggressiveness or fear. It is found that tail elevation indicates a preparation for movement and an increase in pace, except for a full gallop. The explanation may be mechanical and evolutionary: preparation for movement, representing the principal defence of horses against their predators, requires the contraction of anti-gravity muscles, leading to an elevated posture. In this 
way, upright postures have become of communicative value to indicate a preparation for locomotion, alertness and thus warning. It is also used in confident approach and often associated with aggressive intentions (Kiley-Worthington, 1976 and 1997; Hutson and Haskell, 1997; Rees, 1997; McDonnell, 2003; Waring, 2003; Christensen et al., 2005). A drop in postural tonus is shown to be related to fear, mainly in a social context and when flight is not possible. Posture of low tonus, combined often with a protective withdrawal of the tail and ears have therefore become of signal value indicating non-aggression and submission (Kiley-Worthington, 1976 and 1997; Waring, 2003).

Like other demonstrative attitudes, e.g. head shaking, tail wagging likely stemmed from functional movements, such as the intention to reduce cutaneous irritation, and acquired a communication value in social and non-social contexts. Lateral tail movements may be associated with the general motivational state of the animal or to a more specific message, such as the intention to kick. They may also be seen as transitional activity between bouts of ongoing behaviour (Kiley-Worthington, 1976 and 1997) and produce visual as well as auditory signals (Kiley-Worthington, 1976 and 1997; McDonnell, 2003).

Horses may display tail movements when in herd (for review of social organisation, see Linklater et al., 1999; Linklater, 2000) or in the presence of a human, body postures being influenced by the person present (Hausberger and Muller, 2002). Humans, in particular horse workers, must thus be particularly attentive to the movements of the various parts of the horse, which gives precise information on their perception of the situation, including the horse workers' actions. In this way, the International Federation for Equestrian Sports takes the communicative value of tail movements into account, they consider swishing the tail to be one of the 'signs of nervousness, tension or resistance on the part of the horse [which] must be taken into account by the judges in their marks for the movement concerned as well as in the collective mark for "submission"' (Fédération Equestre Internationale, Article 416, 2006).

\section{Potential effects of docking on adult behaviour}

From experiments on positive early handling of foals on fear of humans and manageability in older horses (Mal et al., 1994; Jezierski et al., 1999; Henry et al., 2005; Lansade et al., 2005; Simpson, 2002; Williams et al., 2002), negative early experiences may be suspected of inversely influencing the later behaviour of horses. This has, however, not yet been studied. In addition, adult draught horses are not known for their aggressive behaviour or behavioural anomalies and one can reasonably hypothesise that duration, intensity and/or the unique character of the tail docking experience of foals are insufficient to elicit a marked and durable effect on the behaviour of adult draught horses.

On another side, neonatal pain (circumcision) has been shown to influence responses during subsequent painful procedures (vaccination) in boys (Taddio et al., 1995 and 1997). In the same way, a study on lambs (Kent et al., 2000) suggests a long-lasting increase in pain sensitivity after an episode of intense acute pain (tail docking by rubber ring without anaesthesia). Such a point could be investigated in horses.

\section{Discussion}

This review of the available literature suggests that potential docking advantages are essentially of benefit to humans (see also Cregier, 1990; Dent, 1983; Lips and Aerts, 2006) and that there is no benefit for horses to dock the tails.

From a human point of view, advantages are essentially associated to the potential risks of guiding a horse team with a single rein, or 'cordeau'. Such a problem, concerning only part of the Belgian draught horse population, would hardly allow for systematic docking of the entire population. In addition, the risk potentially linked to this practice, i.e. a whipped leader or tangled tail, has to be demonstrated or infirmed by an epidemiological study. If demonstrated, it may be suggested (i) to maintain the tail hair by bandaging, braiding or shaving or (ii) to adopt alternative methods inspired from other countries. If encountered problems are actually insurmountable, it seems reasonable to suggest adopting the second proposition. Economic, cultural and horse management (ease of gynaecological examinations, for instance) problems also arise when considering the question of tail docking. These aspects have, however, to be scrupulously evaluated in all their complexity, while keeping in mind the absence of advantages, or even the disadvantages for the horses.

From a horse's point of view, in spite of the absence of work evaluating the pain potentially felt by docked foals, studies carried out on similar species showed that this operation is painful, at least temporarily. In conformity with this, the proposed Bill suggests that foal docking may be carried out under light sedation and epidural anaesthesia. Due to mortality and morbidity risks associated with the use of general anaesthesia, it is unadvisable to systematically use this procedure on all newborn of a given species. Concerning the epidural anaesthesia, its efficiency needs improvement, as the evaluation of pain and stress at the amputation time. In the same way, although studies on other mammals strongly suggest post-operative pain and painful health complications after tail docking, these points are still to be evaluated in horses.

In addition, the tail is an important weapon for horses against insect harassment and attacks. It allows their own rear-defence as well as the defence of the head of a congener. In the same way, studies on dairy cows, whose tails have a similar role in insect defence, showed that docked individuals were more subject to insect attacks than intact ones and therefore presented more fly-avoidance behaviour and were more restless, suggesting a reduced welfare. 
Similar studies or studies using physiological parameters have still not been performed on horses. In addition, it is not known whether shivering or stamping with the legs compensate sufficiently. This is an example where considering the available data, one should decide ethically whether one gives the benefit of the doubt to the animal. Lastly, the tail is used as a part of the communication repertoire. Again, up to now, no ethological research has demonstrated that docking affects display to the extent that communication is disturbed. Other elements could be sufficiently informative. In the present case, prohibition of docking does not hamper people from enjoying breeding and working with horses. One can argue that the information available is sufficiently suggestive in order to decide in the advantage of the animal.

This study underlines the subjective aspect of huma$\mathrm{n}$-animal relations. The following example illustrates this point. In the United States, a veterinary surgeon was convicted of negligence for having carried out a tail docking on a 10-year-old stud Quarter Horse. Although the horse was subsequently sent home in good health and his breeding ability was not affected, the court awarded the owner $\$ 34000$ in damages. The court took into account the following elements: the lost stud fees (potential clients not interested in a tailless sire), the embarrassment of owning a tailless stallion and the added expenses required to control flies on the horse (Lewis, 1991). This court decision takes no account of the animal's welfare. It only takes into account the bother caused to the owner by his unwillingly tailless horse and illustrates at what point the value of a horse depends on our human viewpoint.

In conclusion, it should be noted that most West European countries prohibit tail docking in horses, in agreement with the development of European legislation to more restrictive laws concerning animals' amputations and welfare (Pig: 91/630/CEE and 2001/93/CE; Cattle: 91/629/ CEE; Poultry: $\operatorname{COM(2005)221~final).~These~orientations~are~}$ in agreement with a growing tendency in public opinion (Caporale et al., 2005; Eurobarometer IP/05/698) and with studies on other mammals (dairy cattle: Stull et al., 2002; Aubry, 2005; dog: Morton, 1992; Bennett and Perini, 2003; lamb: French et al., 1994a) showing that, in the present state of knowledge, docking is of no benefit to animals and that the advantages for humans could be profitably reconsidered.

\section{Acknowledgements}

The authors thank the Ministry of Social affairs, Security of the Food Chain and Environment (DG4: CITES and Animal Welfare) for its financial support and welcome for this project and the Centre d'Etude et de Recherches Vétérinaires et Agronomiques (CERVA) for its support. They also gratefully thank John Burns for the improvement in English and Ester Peeters and an anonymous referee for their careful reading of this work.

\section{References}

Anand KJS 1990. Neonatal responses to anesthesia and surgery. Clinics in Perinatology 17, 207-214.

Anand KJS, Aranda JV, Berde CB, Buckman SA, Capparelli EV, Carlo W, Hummel $P$, Johnston C, Lantos J, Tutag-Lehr V, Lynn AM, Maxwell LG, Oberlander TF, Raju TNK, Soriano SG, Taddio A and Walco G 2006. Summary proceedings from the neonatal pain-control group. Pediatrics 117, 9-22.

Anderson GSP, Belton P and Kleider N 1991. Culicoides obsoletus as a causal agent of Culicoides hypersensitivity (sweet itch) in horses in British Columbia. Journal of Medical Entomology 28, 685-693.

Aubry P 2005. Routine surgical procedures in dairy cattle under field conditions: abomasal surgery, dehorning, and tail docking. Veterinary Clinics of North America: Food Animal Practice 21, 55-74.

Axelrod J and Reisine TD 1984. Stress hormones: their interaction and regulation. Science 224, 452-459.

Bateson P 1991. Assessment of pain in animals. Animal Behaviour 42, 827-839.

Bennett P and Perini E 2003a. Tail docking in dogs: a review of the issues. Australian Veterinary Journal 81, 208-218.

Bennett P and Perini E 2003b. Tail docking in dogs: can attitude change be achieved? Australian Veterinary Journal 81(5), 277-282.

Blumberg $\mathrm{H}$ and Jänig W 1984. Discharge pattern of afferent fibres from a neuroma. Pain 20, 335-353.

Bonney RJ 2006. Farm animal welfare at work. Applied Animal Behaviour Science 100, 140-147.

Bouillot SN 2002. Le cheval d'attelage en France: situation actuelle et développement. Veterinary thesis. ENV, Toulouse, France.

Brasse-Brossard L 1988. Le manuel du bon charretier. Re-edition of the book edited in 1945. Caracole, Lausanne, Suisse.

Breward J and Gentle MJ 1985. Neuroma formation and abnormal afferent nerve discharge after partial beak amputation (beak trimming) in poultry. Experientia 41, 1132-1134.

Broom DM 2006 . The evolution of morality. Applied Animal Behaviour Science 100, 20-28.

Byford RL, Craig ME and Crosby BL 1992. A review of ectoparasites and their effects on cattle production. Journal of Animal Science 70, 597-602.

Caporale V, Alessandrini B, Dalla Villa P and Del Papa S 2005. Global perspectives on animal welfare: Europe. Revue Scientifique et Technique (International Office of Epizootics) 24(2), 567-577.

Carr T 1979. Caudal adhesion subsequent to tail docking. Canine Practice 6, 63-64.

Christensen JW, Keeling $L$ and Nielsen BL 2005. Responses of horses to novel visual, olfactory and auditory stimuli. Applied Animal Behaviour Science 93, 53-65.

Christie JL, Hewson CJ, Riley CB, McNiven MA, Dohoo IR and Bate LA 2004. Demographics, management, and welfare of nonracing horses in Prince Edward Island. The Canadian Veterinary Journal 45, 1004-1011.

Cogley TP and Cogley MC 1999. Inter-relationship between Gasterophilus larvae and the horse's gastric and duodenal wall with special reference to penetration. Veterinary Parasitology 86, 127-142.

Cogley TP and Cogley MC 2000. Field observations of the host-parasite relationship associated with the common horse bot fly, Gasterophilus intestinalis. Veterinary Parasitology 88, 93-105.

Colter SB and Luttgen PJ 1994a. Electromyographic examination of tail altered horses. Equine Practice 16, 14-17.

Colter SB and Luttgen PJ 1994b. Physical-examination of tail altered horses. Equine Practice 16, 7-9.

Cope SE and Catts EP 1991. Parahost behaviour of adult Gasterophilus intestinalis (Diptera: Gasterophilidae) in Delaware. Journal of Medical Entomology 28, 67-73.

Cregier SE 1990. Shocking docking: mutilation before education? Equine Veterinary Science 10, 252-255.

Dawkins MS 1990. From an animal's point of view: motivation, fitness, and animal welfare. The Behavioral and Brain Sciences 13, 1-61.

Dawkins MS 2004. Using behaviour to assess animal welfare. Animal Welfare (South Mimms, England) 13(Suppl.), 3-7. 
Lefebvre, Lips, Ödberg and Giffroy

Dent A 1983. Shocking docking. Equi (UK) 15, 4-7.

Dinnis AS, Stafford KJ, Mellor DJ, Bruce RA and Ward RN 1999. The behaviour pattern of lambs after castration using a rubber ring/and or castration clamp with or without local anaesthetic. New Zealand Veterinary Journal 47, 198-203. Duncan IJH 2005. Science-based assessment of animal welfare: farm animals. Revue Scientifique et Technique (International Office of Epizootics) 24, 483-492.

Duncan P and Cowtan P 1980. An unusual choice of habitat helps Camargue horses to avoid blood-sucking horse flies. Biology of Behavior 5, 55-60.

Dunlop Cl 1994. Anesthesia and sedation of foals. The Veterinary Clinics of North America: Equine Practice 10(1), 67-85.

Eicher SD and Dailey JW 2002. Indicators of acute pain and fly avoidance behaviours in Holstein calves following tail-docking. Journal of Dairy Science 85, 2850-2858.

Eicher SD, Morrow-Tesch JL, Albright JL and Williams RE 2001. Tail-docking alters fly numbers, fly-avoidance behaviours and cleanliness but not physiological measures. Journal of Dairy Science 84, 1822-1828.

Fédération Equestre Internationale 2006. Article 416: the impulsion/the submission. In Rules for Dressage Events, 22nd edition (ed. FEI), pp. 17-18. Retrieved January 1, 2006, from http://www.horsesport.org/PDFS/D/04_01/ NEWDressageRules2006-E.pdf.

Fenton A, Wall W and French N 1998a. The effect of farm management strategies on the incidence of sheep strike in Britain: a simulation analysis. Veterinary Parasitology 79, 341-357.

Fenton A, Wall R and French N 1998b. The incidence of sheep strike by Lucilia sericata on sheep farms in Britain: a simulation model. Veterinary Parasitology 76, 211-228.

Fischer DW, Beggs JL, Shetter AG and Waggener JD 1983. Comparative study of neuroma formation in the rat sciatic nerve after $\mathrm{CO}_{2}$ laser and scalpel neurectomy. Neurosurgery 13, 287-294.

Foursin M 1995. L'anesthésie du poulain au nouveau-né à 6 mois. Journées Nationales des Groupements Techniques Vétérinaires, 31 mai-1er juin, Angers, France 153-159.

French NP and Morgan KL 1992. Neuromata in docked lambs' tails. Research in Veterinary Science 52, 389-390.

French NP, Wall R, Cripps PJ and Morgan KL 1992. Prevalence, regional distribution and control of blowfly strike in England and Wales. The Veterinary Record 131, 337-342.

French NP, Wall R and Morgan KL 1994a. Lamb tail docking - a controlled fieldstudy of the effects of tail amputation on health and productivity. The Veterinary Record 134(18), 463-467.

French N, Wall R, Cripps PJ and Morgan KL 1994b. Bowfly strike in England and Wales: the relationship between prevalence and farm and management factors. Medical and Veterinary Entomology 8, 51-56.

Gentle MJ 1986. Neuroma formation following partial beak amputation (beak trimming) in the chicken. Research in Veterinary Science 41, 383-385.

Gentle MJ, Thorp BH and Hughes BO 1995. Anatomical consequences of partial beak amputation (beak trimming) in turkeys. Research in Veterinary Science 58, 158-162.

Graham MJ, Kent JE and Molony V 1997. Effects of four analgesic treatments on the behavioural and cortisol responses of 3-week-old lambs to tail docking. Veterinary Journal (London, England) 153, 87-97.

Gross TL and Carr SH 1990. Amputation neuroma of docked tails in dogs. Veterinary Pathology 27, 61-62.

Gunnar M, Connors J, Isensee J and Wall L 1988. Adrenocortical activity and behavioral distress in human newborns. Developmental Psychology 21, 297-310.

Gunnar MR, Hertsgaard L, Larson M and Rigatuso J 1992. Cortisol and behavioural responses to repeated stressors in the human newborn. Developmental Psychobiology 24, 487-505.

Hall M and Wall R 1995. Myiasis of humans and domestic animals. Advances in Parasitology 35, 257-334.

Hamra JG, Kamerling SG, Wolfsheimer KJ and Bagwell CA 1993. Diurnal variation in plasma IR- $\beta$-endorphin levels and experimental pain thresholds in the horse. Life Science 53, 121-129.

Hausberger $M$ and Muller C 2002. A brief note on some possible factors involved in the reactions of horses to human. Applied Animal Behaviour Science 76, 339-344.
Hawkins $P$ 2003. Assessing pain suffering and distress in laboratory animals: an RSPCA survey of current practice in the UK. Animal Welfare (South Mimmms, England) 12, 517-522.

Hay M, Vulin A, Génin S, Sales P and Prunier A 2003. Assessment of pain induced by castration in piglets: behavioral and physiological responses ove the subsequent 5 days. Applied Animal Behaviour Science 82, 201-218.

Heath ACG 1994. Ectoparasites of livestock in New Zealand. New Zealand Journal of Zoology 21, 23-28.

Heidemann S 2002. Le débardage à chevalVeterinary thesisENV, Lyon, France. Heleski CR, Mertig AG and Zanella AJ 2004. Assessing attitudes toward farm animal welfare: a national survey of animal science faculty members. Journal of Animal Science 82, 2806-2814.

Henry S, Hemery D, Richard MA and Hausberger M 2005. Human-mare relationships and behaviour of foals toward humans. Applied Anima Behaviour Science 93, 341-362.

Holm KR, Wennerstrand J, Lagerquist U, Eksell P and Johnston C 2006. Effect of local analgesia on movement of equine back. Equine Veterinary Journal 38 65-69.

Hutson GD and Haskell MJ 1997. Pre-race behaviour of horses as a predictor of race finishing order. Applied Animal Behaviour Science 53, 231-248.

Jezierski T, Jaworski Z and Gorecka A 1999. Effects of handling on behaviour and heart rate in konik horses: comparison of stable and forest reared youngstock. Applied Animal Behaviour Science 62, 1-11.

Johnston GM, Eastment JK, Taylor PM and Wood JLN 2004. Is isoflurane safer than halothane in equine anaesthesia? Results from a prospective multicentre randomised controlled trial. Equine Veterinary Journal 36, 64-71.

Joubert KE, Duncan N and Murray SE 2005. Post-anaesthetic myelomalacia in a horse. Journal of the South African Veterinary Association 76, 36-39 (abstract).

Keiper RR and Berger J 1982. 'Refuges' and pest avoidance: a comparative study of feral horses in desert and island environments. Applied Animal Ethology 9, 111-120.

Kent JE, Molony V and Graham MJ 1998. Comparison of methods for the reduction of acute pain produced by rubber ring castration or tail docking of week-old lambs. Veterinary Journal (London, England) 155, 39-51.

Kent JE, Jackson RE, Molony $\mathrm{V}$ and Hosie BD 2000. Effects of acute pain reduction methods on the chronic inflammatory lesions and behaviour of lambs castrated and tail docked with rubber ring at less than two days of age. Veterinary Journal (London, England) 160, 33-41.

Kiley-Worthington M 1976. The tail movements of ungulates with particular reference to their causation and function as displays. Behaviour 56, 69-115.

Kiley-Worthington M 1997. The behaviour of horses in relation to management and training. J.A. Allen and Company Limited, London, UK.

Lansade L, Bertrand M and Bouissou MF 2005. Effects of neonatal handling on subsequent manageability, reactivity and learning ability of foals. Applied Animal Behaviour Science 92, 143-158.

Le Bars D and Willer JC 2004. Physiologie de la douleur. EMC - Anesthésie Réanimation 1, 227-266.

Leathwick DM, Vlassoff A and Barlow ND 1995. A model for nematodiasis in New Zealand lambs: the effect of drenching regime and grazing management on the development of anthelmintic resistance. International Journal of Parasitology 25, 1479-1490.

Lefebvre D 2006. Caudotomie du cheval de trait Belge. Rapport pour le Conseil du Bien-être animal de Belgique.

Lester SJ, Mellor DJ, Ward RN and Holmes RJ 1991. Cortisol responses of young lambs to castration and tailing using different methods. New Zealand Veterinary Journal 39, 134-138.

Lewis RW 1991. Amputation of the tail of a horse as the basis for a malpractice suit. Journal of the American Veterinary Medicine Association 198 2056-2058.

Lievens JC 2001. Les complications de l'anesthésie générale chez le cheval: étude rétrospective sur 43 cas et 213 témoins. Veterinary thesis. ENV, Lyon, France.

Lightman SL, Windle RJ, Ma XM, Harbuz MS, Shanks NM, Julian MD, Wood SA Kershaw YM and Ingram CD 2002. Hypothalamic-pituitary-adrenal function. Archives of Physiology and Biochemistry 110, 90-93.

Linklater WL 2000. Adaptative explanation in socio-ecology: lessons from the Equidae. Biological Reviews 75, 1-20. 
Linklater WL, Cameron EZ, Minot EO and Stafford KJ 1999. Stallion harassment and the mating system of horses. Animal Behaviour 58, 295-306.

Lips D and Aerts S 2006. Tail docking in horses: tradition, economy, welfare and the future of the Belgian draft horse. In Ethics and politics of food (ed. M Kaiser and M Lien), pp. 533-534. Wageningen Academic Publishers, The Netherlands.

Lizet B 1991. Queues de cheval: fin d'un rite d'élevage et changements actuels du rapport à l'animal. In Maîtres et protecteurs de la nature. Que nous réserve la nature demain? (ed. A Roger), pp. 291-311. Actes du colloque du Creusot, Mâcon, France.

Lizet B 1999. Pour quelques vertèbres de plus. La reconstruction d'une identité du cheval de trait. In L'homme et l'animal: un débat de société (ed. NRA Press), pp. 145-161. INRA, Paris, France.

Loeser JD and Melzack R 1999. Pain: an overview. The Lancet 353, 1607-1609. Lunam CA, Glatz PC and Hsu YJ 1996. The absence of neuromas in beaks of adult hens after conservative trimming at hatch. Australian Veterinary Journal $74,46-49$.

McCarthy RN, Jeffcott LB and Clarke IJ 1993. Preliminary studies on the use of $\beta$-endorphin in horses as an indicator of stress and pain. Journal of Equine Veterinary Science 13(4), 216-219.

McDonnell S 2003. A practical field guide to horse behaviour. The equid ethogram. EP Eclipse Press, Lexington, Kentucky, USA.

McGlone JJ and Hicks TA 1993. Teaching standard agricultural practices that are known to be painful. Journal of Animal Science 71, 1071-1074.

McGlone JJ, Nicholson RI, Hellman JM and Herzog DN 1993. The development of pain in young pigs associated with castration and attempts to prevent castration-induced behavioral changes. Journal of Animal Science 71, 1441-1446.

McGreevy P and Nicol C 1998. Physiological and behavioral consequences associated with short-term prevention of crib-biting in horses. Physiology and Behaviour 65, 15-23.

Mal ME, McCall CA, Cummins KA and Newland MC 1994. Influence of preweaning handling methods on post-weaning learning ability and manageability of foals. Applied Animal Behaviour Science 40, 187-195.

Manteuffel G, Puppe B and Schön PC 2004. Vocalization of farm animals as a measure of welfare. Applied Animal Behaviour Science 88, 163-182.

Marx G, Horn T, Thielebein J, Knubel B and Von Borell E 2003. Analysis of painrelated vocalization in young pigs. Journal of Sound and Vibration 266, 687-698.

Mason GJ and Latham NR 2004. Can't stop, won't stop: is stereotypy a reliable animal welfare indicator? Animal Welfare (South Mimmms, England) 13(Suppl.), 57-69.

Mason BJ, Newton JR, Payne RJ and Pilsworth RC 2005. Costs and complications of equine castration: a UK practice-based study comparing 'standing non-sutured' and 'recumbent sutured techniques'. Equine Veterinary Journal 37, 468-472.

Mathews GJ and Osterholm JL 1972. Painful traumatic neuromas. The Surgical Clinics of North America 52(1), 1313-1324.

Medica DL, Hanaway MJ, Ralston SL and Sukhdeo MVK 1996. Grazing behavior of horses on pasture: prediposition to strongylid infection? Journal of Equine Veterinary Science 16, 421-427.

Mellor DJ and Diesch TJ 2006. Onset of sentience: the potential for suffering in fetal and newborn farm animals. Applied Animal Behaviour Science 100, 48-57.

Mellor DJ and Stafford KJ 2000. Acute castration and/or tailing distress and its alleviation in lambs. New Zealand Veterinary Journal 48, 33-43.

Mercat $L$ 1993. Le cheval comtois, agent de lutte contre les friches? Traits de Génie, Lyon, France.

Molony V and Kent JE 1997. Assessment of acute pain in farm animals using behavioral and physiological measurements. Journal of Animal Science 75 , 266-272.

Molony V, Kent JE and Robertson IS 1993. Behavioural responses of lambs of three ages in the first three hours after three methods of castration and tail docking. Research in Veterinary Science 55, 236-245.

Morton D 1992. Docking of dogs: practical and ethical aspects. The Veterinary Record 131, 301-306.
Morton DB and Griffiths PHM 1985. Guidelines on the recognition of pain, distress and discomfort in experimental animals and an hypothesis for assessment. The Veterinary Record 16, 431-436.

Nebergall SA 1999. How to perform surgical tail docking in draft horses. Proceedings of the American Association of Equine Practitioners 45, 113-114. Noonan GJ, Rand JS, Priest J, Ainscow J and Blackshaw JK 1994. Behavioural observations of piglets undergoing tail docking, teeth clipping and ear notching. Applied Animal Behaviour Science 39, 203-213.

Noonan GJ, Rand JS and Blackshaw JK 1996a. Tail docking in dogs: a sample of attitudes of veterinarians and dog breeders in Queensland. Australian Veterinary Journal 73, 86-88.

Noonan GJ, Rand JS, Blackshaw JK and Priest J 1996b. Behavioural observations of puppies undergoing tail docking. Applied Animal Behaviour Science 49, 335-342.

Olbrich VH and Mosing M 2003. A comparison of the analgesic effects of caudal epidural methadone and lidocaine in the horse. Veterinary Anaesthesia and Analgesia 30, 156-164.

Pape M 1980. L'art de l'attelage - L'attelage et le menage d'après les règles établies par Benno Von Achenbach, 4th edition. Translation of the German book, edited in 1976. Les Presses du Palais Royal, Maloine, Paris, France.

Preece R and Fraser D 2000. The status of animals in Biblical and Christian thought: a study in colliding values. Society and Animals 8, 245-263.

Price J, Marques JM, Welsh EM and Waran NK 2002. Pilot epidemiological study of attitudes towards pain in horses. Veterinary Record 151, 570-575.

Price J, Catriona S, Welsh EM and Waran NK 2003. Preliminary evaluation of a behaviour-based system for assessment of post-operative pain in horses following arthroscopic surgery. Veterinary Anaesthesia Analgesia 30, 124-137. Pritchett LC, Ulibarri C, Roberts MC, Schneider RK and Sellon DC 2003. Identification of potential physiological and behavioral indicators of postoperative pain in horses after exploratory celiotomy for colic. Applied Animal Behaviour Science 80, 31-43.

Proudman CJ, Dugdale AHA, Senior JM, Edwards GB, Smith JE, Leuwer ML and French NP 2006. Pre-operative and anaesthesia-related risk factors for mortality in equine colic cases. Veterinary Journal (London, England) 171, 89-97.

Puppe B, Schon PC, Tuchscherer A and Manteuffel G 2005. Castration-induced vocalisation in domestic piglets, Sus scrofa: complex and specific alterations of the vocal quality. Applied Animal Behaviour Science 95, 67-78.

Ralley WE, Galloway TD and Crow GH 1993. Individual and group-behavior of pastured cattle in response to attack by biting flies. Canadian Journal of Zoology 71, 725-734.

Rees L 1997. The horse's mind. Ebury Press, London.

Rhodes RC, Nippo MM and Gross WA 1994. Stress in lambs (Ovis aries) during a routine management procedure: evaluation of acute and chronic responses. Comparative Biochemistry and Physiology. Part A. Physiology 107, 181-185.

Rollin BE 1985. Animal pain. In M. W. Fox, Advances in animal welfare Science (ed. LD Mickley), pp. 91-105. Martinus, Dordrecht.

Roughan JV and Flecknell PA 2003. Evaluation of a short duration behaviourbased post-operative pain scoring system in rats. European Journal of Pain (London, England) 7, 397-406.

Rutberg AT 1987. Horse fly harassment and the social-behavior of feral ponies. Ethology 75, 145-154.

Said AH and Khami Y 1984. Clinicopathological studies on neurectomy in equids. Equine Veterinary Journal 16, 442-446.

Scadding JW 1981. Development of ongoing activity, mechanosensitivity, and adrenaline sensitivity in severed peripheral nerve axons. Experimental Neurology 73, 345-3643.

Scott EM, Fitzpatrickt JL, Nolan AM, Reid J and Wiseman ML 2003. Evaluation of welfare state based on interpretation of multiple indices. Animal Welfare (South Mimms, England) 12, 457-468.

Short CE 1998. Fundamentals of pain perception in animals. Applied Animal Behaviour Science 59, 125-133.

Sidbäck H 1993. The horse in the forest - caring, training, logging (ed. Gotthard Sennblad), The Swedish University of Agricultural Sciences, Sweden. Simonsen $H B$, Klinken L and Bindseil E 1991. Histopathology of intact and docked pigtails. The British Veterinary Journal 147, 407-412. 
Simpson BS 2002. Neonatal foal handling. Applied Animal Behaviour Science 78, 303-317.

Snoep JJ, Sol J, Sampimon OC, Roeters N, Elbers ARW, Scholten HW and Borgsteede FHM 2002. Myiasis in sheep in The Netherlands. Veterinary Parasitology 106, 357-363.

Soulsby EJL 1982. Helminths, arthropods and protozoa of domesticated animals, 7th edition. Baillère Tindall, London, UK.

Stull CL, Payne MA, Berry SL and Hullinger PJ 2002. Evaluation of the scientific justification for tail docking in dairy cattle. Journal of American Veterinary Medicine Association 220, 1298-1303.

Swanson HH 1961. Traumatic neuromas: a review of the literature. Oral Surgery Oral Medicine Oral Pathology 14, 317-326.

Taddio A, Goldbach M, Ipp M, Stevens B and Koren G 1995. Effect of neonatal circumcision on, pain responses during vaccination in boys. The Lancet 345 , 291-292.

Taddio A, Katz J, Ilersich AL and Koren G 1997. Effect of neonatal circumcision on pain response during subsequent routine vaccination. The Lancet 349, 599-603.

Taylor PM 2003. Editorial. Veterinary Anaesthesia and Analgesia 30, 121-123. Taylor RE 1998. Scientific farm animal production: an introduction to animal science, 6th edn. Prentice-Hall Inc., NJ, USA.

Thiry A 1994. Le débardage à cheval en France. Institut du Cheval, Paris, France. Tozzini S 2003. Hair today, gone tomorrow: equine cosmetic crimes and other tails of woe. Animal Law 9, 159-181.
Tucker CB, Fraser D and Weary DM 2001. Tail docking dairy cattle: effects on cow cleanliness and udder health. Journal of Dairy Science 84, 84-87.

Waring GH 2003. Horse behavior. Noyes Publications, Norwich.

Watts JE and Perry DA 1975. Observations on breech strike in scouring sheep. Australian Veterinary Journal 51, 586-587.

Watts JE and Marchant RS 1977. The effects of diarrhoea, tail length and sex on the incidence of breech strike in modified mulesed Merino sheep. Australian Veterinary Journal 53, 118-123.

Watts JE and Luff RL 1978. The importance of the radical mules operation and tail length for the control of breech strike in scouring Merino sheep. Australian Veterinary Journal 54, 356-357.

Watts JE, Dash KM and Lisle KA 1978. The effect of anthelmintic treatment and other management factors on the incidence of breech strike in Merino sheep. Australian Veterinary Journal 54, 352-355.

Weary DM, Braithwaite LA and Fraser D 1998. Vocal response to pain in piglets. Applied Animal Behaviour Science 56, 161-172.

Weary DM, Niel L, Flower FC and Fraser D 2006. Identifying and preventing pain in animals. Applied Animal Behaviour Science 100, 64-76.

Whay HR and Huxley JN 2005. Pain relief in cattle: a practitioners' perspective. Cattle Practice 13(2), 81-85.

Williams JL, Friend TH, Toscano MJ, Collins MN, Sisto-Burt A and Nevill CH 2002. The effects of early training on the reactions of foals at 1, 2 and 3 months of age. Applied Animal Behaviour Science 77, 105-114. 